University of Rhode Island

DigitalCommons@URI

The Rhode Island Current Conditions Index

Economics

$5-2010$

\title{
Rhode Island Current Conditions Index - May 2010
}

Leonard Lardaro

University of Rhode Island, lardaro@uri.edu

Follow this and additional works at: https://digitalcommons.uri.edu/ricci

Part of the Econometrics Commons

Terms of Use

All rights reserved under copyright.

\section{Recommended Citation}

Lardaro, Leonard, "Rhode Island Current Conditions Index - May 2010" (2010). The Rhode Island Current Conditions Index. Paper 14.

https://digitalcommons.uri.edu/ricci/14

This Article is brought to you for free and open access by the Economics at DigitalCommons@URI. It has been accepted for inclusion in The Rhode Island Current Conditions Index by an authorized administrator of DigitalCommons@URI.For more information, please contact digitalcommons-group@uri.edu. 


\section{BURRENT BDNDITIDNS Index

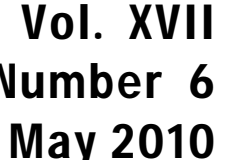

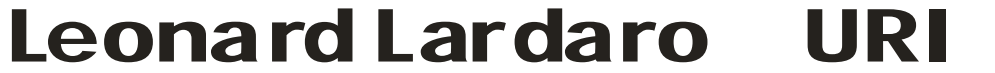

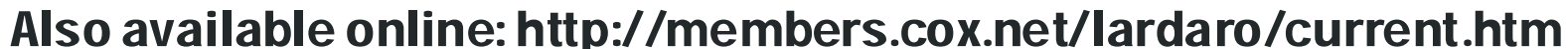

Rhode Island's economy continues to "knock on the door" of the end of its three-year recession. In spite of massive flooding in April, which fortunately occurred as economic activity had begun to rebound, Rhode Island's economy remains very close to a bottom. May's Current Conditions Index reading, 50, appears to be the value at which the $\mathrm{CCl}$ has now plateaued. It must be understood, however, that while there continue to be negative downdrafts for Rhode Island's economy, the recent Census hiring provided some positive offset. Although six of the twelve $\mathrm{CCl}$ indicators improved in May, leading to a neutral reading of 50, if Census hiring is subtracted from Government Employment, then the rare increase in that indicator we witnessed in May $(+1.9 \%)$ would disappear, leading to a $\mathrm{CCl}$ value of 42 . So, the meaning of a $\mathrm{CCl}$ plateau at 50 should become clear from this: an average $\mathrm{CCl}$ of 50 with some months above and others below that value. Consistent with this, it is still quite possible that a recovery will begin here by the end of the third quarter.

May's economic data paint a mixed picture, in spite of a number of relatively easy "comps" from a year ago. On a monthly basis, nine of the twelve indicators either improved or

\begin{tabular}{|c|c|}
\hline \multicolumn{2}{|c|}{ CCI Indicators - \% Change } \\
\hline Government Employment & $1.9 \mathrm{Y}$ \\
\hline US Consumer Sentiment & $6.7 \mathrm{Y}$ \\
\hline Single-Unit Permits & -6.8 \\
\hline Retail Sales & $3.9 \mathrm{Y}$ \\
\hline Employment Services J obs & -5.6 \\
\hline Priv. Serv-Prod Employment & -2.5 \\
\hline Total Manufacturing Hours & -0.5 \\
\hline Manufacturing Wage & $5.7 \mathrm{Y}$ \\
\hline Labor Force & $2.7 \mathrm{Y}$ \\
\hline Benefit Exhaustions & $-23.1 \mathbf{Y}$ \\
\hline New Claims & 10.8 \\
\hline Unemployment Rate & 15.0 \\
\hline$Y=$ I mproved Value & \\
\hline
\end{tabular}

were close to improving. And, even though May's $\mathrm{CCl}$ value was unchanged from April, it handily beat that of last May (17). Importantly, evidence continues to support the contention that our state's manufacturing rebound is being sustained. Total Manufacturing Hours fell by only 0.5 percent in May, their smallest decline in years, as the workweek rose significantly and has returned to a "normal" level. Also, Manufacturing Wage growth remained above 5 percent for the third consecutive month. The question becomes whether this manufacturing strength will be sustained as national manufacturing appears to be weakening?

Looking at the other May indicator performances, US Consumer Sentiment continued to be our "star" performer, rising by 6.7 percent, its fourteenth consecutive year-overyear improvement. This occurred as Retail Sales rose for the fourth consecutive month (note: these were estimated until a final figure is released). Single-Unit Permits fell by 6.8 percent compared to a year ago, as there continues to be virtually no new home construction in Rhode Island. According to the official data, our state's Labor Force rose again, increasing by 2.7 percent, while our Unemployment Rate fell slightly to 12.3 percent.

The overall labor market picture was mixed. Employment Service Jobs, a leading labor market indicator, fell 5.6 percent, remaining almost unchanged since November. Private Service-Producing Employment declined again, by 2.5 percent. As noted earlier, Government Employment actually rose in May, assisted by Census hiring, while Total Manufacturing Hours fell by their lowest rate since December of 2006, boosted by a large increase in the workweek $(+1.7$ hours). Benefit Exhaustions, which reflects long-term unemployment, fell sharply, by 23.1 percent in May, its third consecutive improvement, and New Claims, a leading indicator that measures layoffs, rose by 10.8 percent versus last May, while falling relative to April's level which was inflated by post-flood unemployment.

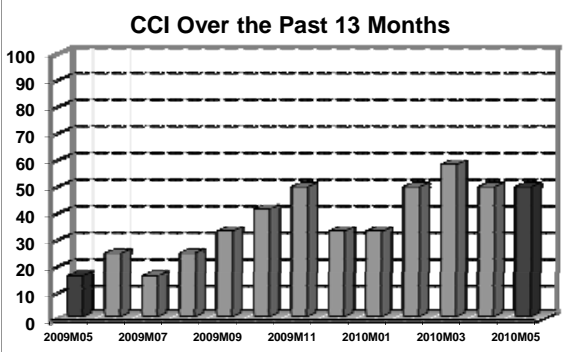

\section{THE BOTTOM LINE}

For May, Rhode Island's economy remained in neutral, as the $\mathrm{CCl}$ once again registered a value of 50 . As we move forward, will we shift into a higher gear and actually begin a recovery or will we remain in neutral or downshift? Large state budget deficits and a slowing pace of national economic activity will certainly provide headwinds for us. The most relevant question is therefore: What is our state's engine of growth?

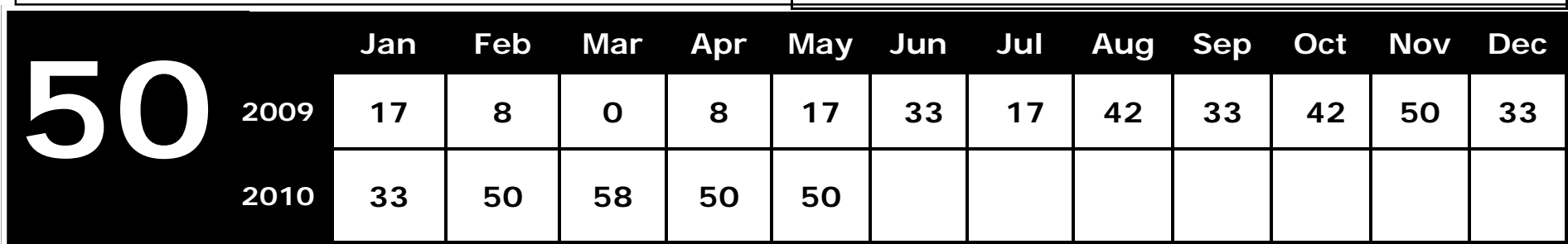

